\title{
EVALUATION OF TIMBER HARVESTING PLANNING IN INDONESIAN GERTIFIED SMALL AND LOW-INTENSITY MANAGED FORESTS
}

\author{
Hermudananto* \& Supriatno N \\ Universitas Gadjah Mada, Faculty of Forestry, Yogyakarta 55281, Indonesia \\ *hermudananto@ugm.ac.id
}

Submitted July 2019; accepted February 2020

\begin{abstract}
At present, Indonesian certified small- and low intensity-managed forests area (hereafter community forests) are consistently increasing with the growth of smallholder or privately owned forests (hutan rakyat). Timber harvesting planning poses a challenge for community groups to implement their agreed upon harvesting plan, because farmers may delay harvesting schedule or cut the trees earlier (harvesting needs). This study aims to evaluate timber harvesting planning in Indonesian certified community forests by comparing annual harvesting targets and the actual cutting, following discussions with farmers and forest managers. Through observation, interviews and data analyses of two Forest Stewardship Council certified sites, CV. Dipantara and Koperasi Wana Lestari Menoreh, we found that almost every year, forest managers could not strictly push farmers or members to meet the annual harvesting target. It was mostly due to unexpected events on the part of farmers, e.g. marriage, celebrations, illness, or even not needing money during the harvesting period. Consequently, the group of certified community forests was unable to supply wood continuously to industries due to low timber production. The forest certification board should also review their standard requirements to bring them in line with the actual conditions of community forests in order to achieve sustainable forest management goals.
\end{abstract}

Keywords: Forest Stewardship Council, sustainable forest management, community forests, annual allowable cut, smallholder forests, tropical forests

\section{INTRODUCTION}

The emergence of Indonesian small- and low intensity-managed forests (hereafter community forests) was driven by a greening programme initiated by the government in 1975 , especially in watersheds that were considered critical, including damaged forests, thickets, bare land and abandoned land (BPKH 2009). In subsequent developments, these forests contributed to the supply of raw material (logs) to wood industries in 2007-2011, and contributed to the growth of community forest areas and log productivity in Java (the most populated island in Indonesia) (Astana et al. 2014). The area and estimated production of community forests in Indonesia in 2003 were 1,560,229 ha and 39,564,003 $\mathrm{m}^{3}$ respectively (Darusman \& Hardjanto 2006). Teak (Tectona grandis), mahogany (Swietenia macrophylla), sengon (Paraserianthes falcataria) and jabon (Anthocephalus cadamba) are several common species supplied to industries for sawn timber, furniture, or plywood products.
Market demand for environmentally friendly forest products is driven by green consumers in developed countries who indirectly push producers of raw materials especially in developing countries to adhere to their conditions and maintain their businesses in the forestry sector. The development of community forest certification is necessary to meet the economic, social and environmental aspects of production, environmental stewardship and social sustainability (Hinrichs et al. 2008). At least two initiated certification schemes, the Indonesian Ecolabel Institute (LEI) and the Forest Stewardship Council (FSC), began to recognise forest certification for the management of several community forests in Indonesia in 2004. Specifically, the second scheme includes international requirements that are adjusted and adapted to national or local regulations.

One consideration is that community forests also have unique characteristics in terms of 
timber harvesting and managing their forest products compared with natural forest or large plantation management. Farmers tend to harvest timber when they really need to, for instance, to finance tuition fees, and for celebrations or home construction (Hinrichs et al. 2008). In the community forests, these situations are called harvesting needs (locally known as tebang butuh). It is assumed that timber harvesting planning which ensured sustainable yields in certified forests can resolve these issues. However, scientific studies of certified community forests and harvesting planning have not been widely carried out and still focus on institutional issues (Yumi et al. 2012) and the impact of certification (Kazuhiro et al. 2012, Fujiwara et al. 2015). Generally, farmers consider forests as long-term assets which will be harvested when there is a need (Hinrichs et al. 2008) and depending on their socio-economic conditions (Fujiwara et al. 2017).

Therefore, an evaluation of timber harvesting planning practices in community forests is necessary to answer whether the agreed upon annual harvesting target (annual allowable cut) can be achieved when forest certification exists, in this case, under the FSC scheme. Understanding the opportunities and challenges of its implementation will be helpful to meet future demand for raw materials from wood industries.

\section{MATERIALS AND METHODS}

\section{Study sites}

Two FSC certified community forests (CV. Dipantara and Koperasi Wana Lestari Menoreh) were selected in the Special Region of Yogyakarta, Indonesia. The first unit has an FSC certificate \#BV-FM/COC-137288 valid to 12 February 2023, while the second one, managed by PT. Sosial Bisnis Indonesia, has FSC code \#SGS-FM/COC011027 valid to 10 May 2022. Both forests have different scopes of forest certification (Table 1) and act as third parties (brokers) for their members/farmers to sell and promote certified logs.

\section{Data collection}

Primary and secondary data were collected in April-September 2018. Primary data included indepth interviews with representatives of farmers and forest managers, and field observations. A list of interview questions that have been discussed between authors and experts in community forests at the Faculty of Forestry, Universitas Gadjah Mada were used consistently. Sample of questions to farmers are:

(1) When is your harvesting plan scheduled in the management plan?

(2) Why did you cut your trees before or after the scheduled harvesting plan?

(3) How did the forest manager set up the harvesting plan for your land?

These questions helped us to understand what motivated farmers to cut their trees in a given period and how forest managers planned their annual harvesting targets. Secondary data (for the last 5 years) including annual harvesting plans, actual quantities of annual logging (harvesting records), and FSC audit reports (describing compliance in harvesting target issue), were also reviewed.

Table 1 Summary of study sites

\begin{tabular}{lll}
\hline Information & CV. Dipantara & Koperasi Wana Lestari Menoreh \\
\hline Location & Gunung Kidul & Kulon Progo \\
Year established & 2006 & 2008 \\
Certified area (ha) & 375.45 & 832.937 \\
Species (scope) & Acacia (Acacia spp.), teak & Acacia (Acacia spp.), sonokeling (Dalbergia latifolia), \\
& $($ Tectona grandis) and mahogany & sengon (Paraserianthes falcataria), mahogany (Swietenia \\
& $($ Swietenia spp.) & spp.), teak (Tectona grandis) \\
Group farmers/members & $>100$ group farmers & $>1000$ members \\
Forest certification & FSC, SVLK & FSC, SVLK, LEI \\
NGOs & The Forest Trust, Sumber Raya & Telapak, Yayasan Bina Insan Mandiri \\
\end{tabular}




\section{Data analysis}

Descriptive methods were applied in this study. All collected data were analysed and described by comparing annual volume of timber in cubic meters and the annual harvesting plans for the last 5 years.

\section{RESULTS AND DISCUSSION}

\section{Establishing a harvesting plan}

Both certified community forests (CV. Dipantara and Koperasi Wana Lestari Menoreh) applied tree inventory data for all members as a basis to establish annual harvesting in their management plans. Minimum tree circumference or diameter were measured in the two community forests following their standard operating procedures (Table 2). The inventory data were then used as reference to develop the annual allowable cut as a limit or target for sustainable forest product harvesting for each tree species within the scope of forest management.

Community forests, just as natural forests or large plantations, should establish a harvesting plan as part of their forest certification. Besides specifying the number of logs that can be harvested sustainably with suitable harvesting methods or equipment, an annual harvesting target may help forest managers to supply an appropriate number of logs to wood industries. The harvesting plan for each member in both community forests covered annual targeted trees based on forest inventory data, but information on farmers' needs in terms of money in the future was not fully considered (e.g. for building house, marriage). In forest certification, an agreed upon harvesting plan must be implemented to achieve sustainable forest management goals (Hinrichs et al. 2008).

The FSC certified community forests were not developed by the community themselves, instead they needed support from other parties in terms of finance and technical practice of forest management. Non-governmental organisations (NGOs) provide technical support (including annual harvesting plan) and facilitate in achieving sustainable forest management and promote green forest products (Hinrichs et al. 2008). The Forest Trust and the Sumber Raya Alam Conservation Group are two NGOs in CV. Dipantara, while the local NGO Telapak contribute fully to pioneering forest management at Koperasi Wana Lestari Menoreh, which is currently managed by PT. Sosial Bisnis Indonesia. The two cooperatives not only manage their forest members but also act as third parties (also known as brokers) that connect the farmers' raw materials (logs) to market demand (buyers).

Although a forest manager is responsible for forest certification, farmers as landowners have full rights to manage their own land. They sometimes make decisions that affect implementation of forest certification in a group. The farmers may postpone their harvesting period or cut their trees earlier depending on their needs (e.g. tuition fees, marriages, celebrations). These incidences may threaten the goals towards sustainable forests based on agreed harvesting plans.

\section{Evaluating actual harvesting}

Forest harvesting operations in both certified community forests were implemented on the basis of planned harvesting procedures. Harvesting teams immediately transported logs to the wood

Table 2 Summary of criteria in forest inventory

\begin{tabular}{lll}
\hline Information & CV. Dipantara & Koperasi Wana Lestari Menoreh \\
\hline Inventory & 3 years & 5 years \\
Inventory tree circumference & Min $60 \mathrm{~cm}$ & Min $25 \mathrm{~cm}$ \\
Harvested tree circumference & Min $70 \mathrm{~cm}$ & Min $85 \mathrm{~cm}$ \\
Harvested tree diameter & Min $25 \mathrm{~cm}$ & Min $30 \mathrm{~cm}$ (teak, mahogany, sonokeling) \\
& & Min $20 \mathrm{~cm}($ sengon) \\
Assumption of mean annual & $1 \mathrm{~cm}($ teak) & $1.5 \mathrm{~cm}, 2 \mathrm{~cm}, 1 \mathrm{~cm}$ and $4 \mathrm{~cm}$ for teak, \\
increment & & mahogany, sonokeling, sengon respectively \\
Year harvesting plan (existing) & $2010-2014,2015-2019$ & $2010-2014,2016-2026$ \\
\hline
\end{tabular}


collection point (log yard) after cutting them down using chainsaw. Harvesting was conducted when logs were requested by buyers, which were mostly from Central Java. Actual harvesting in CV. Dipantara fluctuated yearly depending on market requests and current needs of farmers (Table 3). Therefore, annual harvesting targets were not fully achieved. In Koperasi Wana Lestari
Menoreh, the actual harvested volume was never achieved and always below the annual allowable cut since 2013 (Table 4).

Based on actual harvesting records for the period 2013-2017 in both certified community forests, it seemed difficult for farmers to achieve their annual harvesting projections, except for one year (2016) in CV. Dipantara. The

Table 3 Summary of annual planned and actual harvesting for 2013-2017 at CV. Dipantara

\begin{tabular}{llcc}
\hline Year & Species & Harvesting plan $\left(\mathrm{m}^{3}\right)$ & Actual harvesting $\left(\mathrm{m}^{3}\right)$ \\
\hline 2017 & Teak & 1232 & 0 \\
& Mahogany & 760 & 0 \\
\multirow{2}{*}{2016} & Acacia & 570 & 0 \\
& Teak & 1232 & 1690 \\
& Mahogany & 760 & 1,201 \\
\multirow{2}{*}{2015} & Acacia & 570 & 713 \\
& Teak & 1967 & 503 \\
& Mahogany & 449 & 0 \\
& Acacia & - & - \\
& Teak & 1967 & 777 \\
& Mahogany & 449 & 151 \\
& Acacia & - & - \\
& Teak & 2096 & 1500 \\
& Mahogany & 330 & 0 \\
& Acacia & - & - \\
\hline
\end{tabular}

Table 4 Summary of annual planned and actual harvesting for 2013-2017 at Koperasi Wana Lestari Menoreh

\begin{tabular}{llcc}
\hline Year & Species & Harvesting plan $\left(\mathrm{m}^{3}\right)$ & Actual harvesting $\left(\mathrm{m}^{3}\right)$ \\
\hline 2017 & Teak & 435.0 & 206.5 \\
& Mahogany & 334.0 & 151.8 \\
& Sengon & 588.0 & 90.9 \\
& Sonokeling & 54.0 & 0.0 \\
& Teak & 621.0 & 435.0 \\
& Mahogany & 464.0 & 334.0 \\
& Sengon & 658.0 & 588.0 \\
& Sonokeling & 61.0 & 54.0 \\
& Teak & 621.6 & 363.5 \\
& Mahogany & 464.6 & 363.6 \\
& Sengon & 658.7 & 7.4 \\
& Sonokeling & 61.3 & 0.4 \\
& Teak & 621.6 & 363.5 \\
& Mahogany & 464.6 & 363.6 \\
& Sengon & 658.7 & 7.4 \\
& Sonokeling & 61.3 & 0.4 \\
& Teak & 566.6 & 479.4 \\
& Mahogany & 440.3 & 223.5 \\
& Sengon & 635.4 & 30.8 \\
& Sonokeling & 57.8 & 2.4 \\
\hline \multirow{2}{*}{2013} & & &
\end{tabular}


over harvesting in 2016 was recorded in the FSC public report as a non-conformity that needed to be followed up by the community forest especially in criteria 5.6 of FSC standard about the harvesting rate of forest products not exceeding the set limit. Regulations for minimum tree circumference and diameter were sometimes not fully implemented properly by both community forests. Stand management was generally accomplished by selective logging, whereby farmers leave several stands for future needs (Hamdani et al. 2015). Cutting down trees to earn income was the last resort for farmers. Farmers only harvest their trees to meet various urgent needs, such as home renovations, tuition fees, celebrations and medical treatments (Hamdani et al. 2015). Sales of food crops or livestock (e.g. cows, goats or chickens) were generally preferred prior to cutting down trees (Hinrichs et al. 2008).

As members of cooperatives, forest certification benefits the farmers. However, sustainability issues pose a challenge to forest managers during its implementation. Understanding better forest management practices was one advantage, but high certification costs was another consideration in maintaining compliance with forest management schemes (Maryudi 2009). Besides timber extraction, several farmers were also involved in agriculture and livestock to fulfil their daily needs.

\section{Certified community forests}

Our results showed that cutting needs and delaying harvest still occurred even though a comprehensive harvesting plan existed in the certified community forests. Through data collection and interviews we observed that, in several cases, actual cutting exceeded or was below the annual target. It was also observed that diameters of several harvested trees were below the minimum established limits and several logging activities were conducted without official reporting to forest managers. Challenges faced by farmers and forest managers in maintaining forest certification included low budgets to manage harvesting needs, competition in log prices paid by brokers, inconvenience in administration (forest certification needed regular audits, thus more records/documentation, i.e. more paperwork) of timber harvesting and transportation activities between cooperatives or brokers, and difference in methods of payment between FSC-certified and non-certified timber. Payment was easier for local traders or brokers (Hinrichs et al. 2008, Wiyono et al. 2018), as they were closer (location) to members' land compared with nonlocal ones (Hamdani et al. 2015). We also found out that some members sold certified timber as non-certified products. Koperasi Wana Lestari Menoreh came up with a strategy for members who needed urgent funds when their trees had not yet reached the minimum tree diameter or circumference-they loaned money to farmers/ members with trees as collateral and accepted payment later when the trees were suitable for cutting (Wiyono et al. 2018).

Certified logs are generally priced higher than non-certified ones. At least $15-35 \%$ of certified logs are obtained from timber that was considered from sustainable forest management (Maryudi 2009). With the higher price, members are expected to follow the regulations set forth by forest managers regarding the harvesting plan for forest products. Log prices were determined periodically and communicated to its members transparently and was easily accessible. However, its conditions did not immediately motivate members to sell their logs to the cooperatives, because some administrative issues took several days to be processed, including verifying the quantity and quality of logs. This situation needs to be monitored by forest managers to avoid any impact on their forest certification. Additionally, FSC-scheme owners should consider in their standards that sustainable production may only be achieved by fulfilling annual harvesting plan from each certified community forest.

\section{CONGLUSIONS}

Harvesting plans for certified community forests may be improved by including information about the farmers' future needs (e.g. building house, marriage, future predicted events) and forest inventory data. Two cases in CV. Dipantara and Koperasi Wana Lestari Menoreh indicated that it was difficult for community forests to achieve annual harvesting targets due to lack of implementation of their agreed upon forest harvesting plan, including farmers' motivations. As a last resort, timber was only cut down by farmers to meet urgent needs. This situation caused delay in harvest or even cutting trees earlier. As a result, harvesting targets could not be 
attained. A strong commitment to implement the agreed upon harvesting plan between farmers and forest managers is needed to achieved sustainable community forests. This way, the community forests will be able to periodically supply raw materials to wood industries.

\section{ACKNOWLEDGEMENTS}

This research was supported and funded by Faculty of Forestry Universitas Gadjah Mada. The authors would like to thank CV. Dipantara and Koperasi Wana Lestari Menoreh (PT. Sosial Bisnis Indonesia) for providing data.

\section{REFERENCES}

Astana S, Obidzinski K, Riva WF, Hardiyanto G, Komarudin H \& SukANDA. 2014. Implikasi biaya dan manfaat pelaksanaan SVLK terhadap sektor perkayuan skala kecil. Jurnal Penelitian Sosial dan Ekonomi Kehutanan 11: 175-198. https://dx.doi.org/10.20886/ jpsek.2014.11.3.24.

BPKH. 2009. Potensi Kayu dan Karbon Hutan Rakyat di Pulau Jawa Tahun 1990-2008. Balai Pemantapan Kawasan Hutan Wilayah XI Jawa-Madura and Forest Governance and Multi-Stakeholders Forestry Programme, Yogyakarta.

Darusman D \& Hardjanto. 2006. Tinjauan ekonomi hutan rakyat. Pp 4-13 Prosiding Seminar Hasil Litbang Hasil Hutan: Kontribusi Hutan Rakyat dalam Kesinambungan Industri Kehutanan. 21 September 2006, Bogor.

Hinrichs A, Muhtaman DR \& Irianto N. 2008. Sertifikasi Hutan Rakyat di Indonesia. Deutsche Gesellschaft für Technische Zusammernarbeit (GTZ). Jakarta.
Fujiwara T, Awang SA, Widayanti WT, Septiana RM, Hyakumura \& SATO N. 2015. Effects of national community-based forest certification on forest management and timber marketing: a case study of Gunung Kidul, Yogyakarta, Indonesia. International Forestry Review 17: 448-460. https://doi.org/10.1505/146554815817476422.

Fujiwara T, Awang SA, Widayanti WT, Septiana RM, Hyakumura K \& Sato N. 2017. Socioeconomic conditions affecting smallholder timber management in Gunungkidul District, Yogyakarta Special Region, Indonesia. Journal of Small-Scale Forestry 17: 41-56. https://doi.org/10.1007/s11842-017-9374-1.

Hamdani FAU, Darusman D \& Tiryana T. 2015. Evaluasi praktik tebang butuh di hutan rakyat Kabupaten Ciamis Provinsi Jawa Barat. Jurnal Risalah Kebijakan Pertanian dan Lingkungan 2: 33-41. https://doi. org/10.20957/jkebijakan.v2il.10387.

Kazuhiro H, Rohman, Oktalina SN \& Wiyono. 2012. Exploring potential of forest certification for community-based forest management in Indonesia. Journal of Forest Economics 58: 58-67. https://doi. org/10.20818/jfe.58.1_58.

MarYudi A. 2009. Forest Certification for Community-Based Forest Management in Indonesia: Does LEI Provide a Credible Option? IGES, Hayama.

Wiyono W, Oktalina SN \& Hidayat R. 2018. Analisis rantai pemasaran kayu sertifikasi FSC di Kabupaten Kulon Progo. Jurnal Nasional Teknologi Terapan 2: 169-178. https://doi.org/10.22146/jntt.39167.

Yumi, Sumardjo, Gani DS \& Sugihen BG. 2012. Kelembagaan pendukung pembelajaran petani dalam pengelolaan hutan rakyat lestari (kasus di Kab. Gunung Kidul, Provinsi Daerah Istimewa Yogyakarta dan Kabupaten Wonogiri, Provinsi Jawa Tengah). Jurnal Penyuluhan 8: 15-28. https://doi.org/10.25015/penyuluhan. v8i1.9891. 